\title{
A STUDY ON OIL FIELD SANDSTONE THROUGH POROSITY
}

\section{AND PERMEABILITY PARAMETERS}

\section{A. SIVASAKTHI}

Department of Petroleum Engineering, Academy of Maritime Education and Training (AMET), Chennai, India

Crude oil reservoirs have different formation types according to their environmental and geological conditions. Sandstone is one of the most common formations of crude oil reservoir, which has high oil bearing capacity than carbonate formation. In this research article, oil field sandstone was collected and analysed through porosity and permeability. The sandstone was visually observed for the classification of sandstone. The porosity of the sandstone was determined by porosimeter equipment and found to be $10.93 \%$. The permeability of sandstone was measured in the gas permeameter and found to be $0.084 \mathrm{mD}$. The core flooding operation gives an idea about the recovery efficiency of particular core and crude oil. The oil recovery efficiency of water flooding and chemical flooding was found to be $35 \%$ and $42.23 \%$. The recovery of crude oil was slightly less in the water flooding mechanism due to the low porosity and permeability of sandstone. The determination of rock characterization in the initial stage helps in finding the better recovery technique, suitable for the oil production.
\end{abstract}

KEYWORDS: Carbonate, Permeability, Porosity, Recovery, Sandstone \& Water Flooding

Received: Jul 14, 2018; Accepted: Aug 04, 2018; Published: Aug 24, 2018; Paper Id: IJMPERDOCT20188

\section{INTRODUCTION}

Crude oil reservoirs rocks are mainly of two types, namely sandstone and carbonate. Sandstone rocks are often occurred in the deserts, land and river environmental conditions, while carbonate rocks can be observed in the marine conditions due to the presence of abundant marine dead organisms and high calcium deposits (Leo $\mathrm{C}$ van Rijn 2013, SKAT 1992). Sandstone is a sedimentary rock that is formed by the large amount of quartz mineral with small amount of feldspar, cementing materials and rock fragments. By the geological actions such as compaction and cementation, quartz mineral along with the feldspar and rock fragments are compressed with the cementing materials to create sand stone (SN Ehrenberg and P H Nadeau 2005, Teoh Ying Jia 2007).

Sandstone is categorized as quartz arenites, Feld spathic sandstone, lithic sandstone and greywacke based on the texture and grain composition. Quartz arenites contains more than $95 \%$ of quartz grains, while arkoses arenites contains more than $25 \%$ of feldspar grains. Greywacke is the transitions region between arenites and mudstones that has less than $75 \%$ of quartz content (A Hurst and J SArcher1986, Robert R Berg1986).

The porosity and permeability of the sandstone play a major role in the oil bearing capacity and crude oil production. Porosity of the sandstone is the amount of void space that are unoccupied by any mineral in a specific rock. Porosity is the ratio of pore volume to the bulk volume. Pore volume is the volume of void space in the sandstone, whereas bulk volume is the volume of void space and solid volume in the rock. Porosity of the reservoir sandstone is $15-35 \%$ and compact sandstone value ranges from 1 to $15 \%$ (Xuetao $\mathrm{Hu}$ and Su Huang 2017). 
Permeability is the ability of sandstone to transmit fluid through the pore network in the rocks. Permeability measurement is useful in the crude oil recovery and production processes. Permeability of the sandstone is measured in Darcy and a rock, whose permeability is $5 \mathrm{mD}$ or less is called tight sandstone, or a dense limestone depending upon the mineral composition (Xuetao Hu and Su Huang 2017).

In this research article, sandstone sample was analysed for the basic parameters namely bulk density, porosity and permeability. The basic parameter gives the important details about the reservoir oil bearing ability and further production type selections. The helium porosimeter and gas permeameter were used for the measurement of porosity and permeability of sandstone.

\section{MATERIALS REQUIRED}

The oil field sandstone was collected from the Cauvery basin for the experimental studies. The apparatus required for the examinations are helium porosimeter, gas permeameter and soxhlet apparatus, besides, the chemical necessary is toluene.

Table 1: Specification of Collected Sandstone

\begin{tabular}{|c|l|l|}
\hline S. No. & Specifications & \multicolumn{1}{c|}{ Dimensions } \\
\hline 1. & Length & $15 \mathrm{~cm}$ \\
\hline 2. & Diameter & $3 \mathrm{~cm}$ \\
\hline 3. & Depth & $3770 \mathrm{~m}$ \\
\hline 4. & Formation type & Sandstone \\
\hline 5. & Rock type & Sedimentary rock \\
\hline 6. & Shore type & Onshore well \\
\hline
\end{tabular}

\section{METHODOLOGY}

\section{Visual Observations}

The colour of the sandstone was visually noted for the sand minerals distinguish. The colour of the sandstone was created by the minerals that were present in the formation. The classification of sandstone based on the grain composition is namely arenites, greywackes and mudstones (Robert R Berg1986).

Table 2: Different Minerals of Sandstone

\begin{tabular}{|l|l|l|l|}
\hline & \multicolumn{3}{|c|}{ Sandstone Mineral Components } \\
\hline $\begin{array}{l}\text { Name of the } \\
\text { Minerals }\end{array}$ & Quartz & Feldspar & Rock fragments \\
\hline $\begin{array}{l}\text { Structure of the } \\
\text { Minerals }\end{array}$ & $\mathrm{SiO}_{2}$ & $\begin{array}{l}\left(\mathrm{KAlSi}_{3} \mathrm{O}_{8}-\right. \\
\mathrm{NaAlSi}_{3} \mathrm{O}_{8}- \\
\left.\mathrm{CaAl}_{2} \mathrm{Si}_{2} \mathrm{O}_{8}\right) \mathrm{n}\end{array}$ & $\begin{array}{l}\text { Igneous, metamorphic or } \\
\text { sedimentary rock particles }\end{array}$ \\
\hline $\begin{array}{l}\text { Color of the } \\
\text { Minerals }\end{array}$ & $\begin{array}{l}\text { Colorless from } \\
\text { white to colorless }\end{array}$ & Pink, brown, grey & Red, grey, black, orange \\
\hline $\begin{array}{l}\text { Density of the } \\
\text { Minerals (g/cm }\end{array}$ & 2.648 & 2.56 & - \\
\hline Specific Gravity & 2.65 & $2.55-2.76$ & - \\
\hline
\end{tabular}

\section{Determination of Porosity}

Sandstone sample was initially subjected to soxhlation with toluene for the removal of organic compounds. After soxhlation, sandstone sample was placed in the hot air oven at $120{ }^{\circ} \mathrm{C}$ for 24 hours for solvent evaporation. Porosity is defined as the ratio of pore volume to bulk volume, in which, pore volume is the difference between bulk 
volume and grain volume. The collected sandstone was observed to be a regular cylindrical shape, and the bulk volume is the volume of cylinder. Sandstone sample was measured for the length and diameter with the digital vernier caliper.

Helium porosimeter is based on the Boyle-Maritte's law that is reference pressure and volume equals expansion pressure and volume. During the entire experiment, temperature of the system is assumed to be kept constant. It uses a matrix cup and specific software for the direct determination of porosity and grain volume. Grain volume is the volume of solids present in the sandstone. Helium porosimeter is capable of measuring porosity up to $60 \%$.

\section{Determination of Permeability}

Sandstone was placed in the core holder of gas permeameter, and nitrogen at constant flow rate was forced through the sandstone core and the differential pressure across the core was measured. The gas permeameter uses particular software to analyse the pressure difference and calculate the permeability of the sandstone with the help of Darcy law. Darcy law is given by

$$
\mathrm{Q}=(\mathrm{kA} \Delta \mathrm{p}) /(\mu \mathrm{L})
$$

In the above equation, $\mathrm{Q}$ is the total gas flow rate, $\mathrm{K}$ is the permeability of sandstone in Darcy and $\mathrm{A}$ is the cross-sectional area of the sandstone, $\Delta \mathrm{p}$ is the difference in pressure of the inlet and outlet gas, $\mu$ is the viscosity and $\mathrm{L}$ is the length of the sandstone sample. Once the data of length and diameter of sandstone were entered in the software, and the measured differential pressure provides permeability value.

\section{Core Flooding Operations}

A core flooding apparatus was constructed with the dimensions of $20 \mathrm{~cm}$ in length and $1.75 \mathrm{~cm}$ in diameter. The bottom of the core flooding apparatus was fitted with $100 \mathrm{~mm}$ mesh and sandstone was placed inside the apparatus for experimental investigation (Rajesh Kanna A et al 2014, Samadi NN et al 2007). The column was flooded with brine (5\% Nacl) and ensures that the column was $100 \%$ saturated. The pore volume of the column was calculated by measuring the volume of brine required to saturate the column (PV). Next, the column was saturated with medium crude oil in the same way as brine, until residual brine saturation was reached. As oil entered into the column, brine was displaced and discharged to the bottom of the column. Initial oil saturation $\left(\mathrm{S}_{\mathrm{oi}}\right)$ was calculated by measuring the volume of brine displaced by oil saturation, also called original oil in place (OOIP).

Initial oil recovery was done by water flooding with brine, so the sand pack column was again flooded with 10-11 Pore volume of brine until there was no more oil found in the effluent, that is the residual oil saturation $\left(\mathrm{S}_{\mathrm{or}}\right)$ was reached. The amount of crude oil retained in the sand pack was determined volumetrically. $\mathrm{S}_{\text {or }}$ was calculated by measuring the volume of displaced oil. Triton was passed through the column similar to brine and oil and incubated for 24 hours, then the column was again flooded with brine. Discharges from the column were collected to measure the amount of oil recovered using chemical surfactant (Suthar H et al 2008).

The percentage of oil recovered was calculated as follows,

$$
\begin{array}{ll}
\text { Initial Water Saturation, } \mathrm{S}_{\mathrm{wi}}(\%) & =((\mathrm{PV}-\mathrm{OOIP}) / \mathrm{PV}) \times 100 \\
\text { Initial Oil Saturation, } \mathrm{S}_{\mathrm{oi}}(\%) & =(\mathrm{OOIP} / \mathrm{PV}) \times 100 \\
\text { Residual Oil Saturation, } \mathrm{S}_{\text {or }}(\%) & =\left(\left(\mathrm{OOIP}-\mathrm{S}_{\text {orwf }} / / \mathrm{OOIP}\right) \times 100\right.
\end{array}
$$


Additional Oil Recovery,
$\operatorname{AOR}(\%)$
$=($ Oil recovered using chemical surfactant $/$ Oil in column after water flooding $) \times 100$
AOR $(\%)$
$=\left(\mathrm{S}_{\text {orcf }} /\left(\mathrm{OOIP}-\mathrm{S}_{\text {orwf }}\right)\right) \times 100$
Where,
Pore Volume $(\mathrm{PV})(\mathrm{ml}) \quad$ = Volume of brine required to saturate the column
Original Oil in Place $(\mathrm{OOIP})(\mathrm{ml})=$ Volume of brine displaced by oil saturation
$\mathrm{S}_{\text {orwf }}(\mathrm{ml}) \quad$ = Oil recovered after water flooding
$\mathrm{S}_{\text {orcf }}(\mathrm{ml}) \quad$ = Oil collected over residual oil saturation after chemical flooding

\section{RESULTS AND DISCUSSIONS}

\section{Visual Colour Observation}

The colour of the sandstone was visually observed. The sandstone was found to have major white colour and small amount of brown colour. The white colour may be the presence of quartz mineral or cementing materials. The small amount of brown colour is the presence of feldspar and impurities. Further characterization of sandstone will give the clear information of the core sample.

\section{Determination of Porosity}

Length and diameter of the sandstone were calculated by digital venier caliper. The bulk volume of the sandstone was found to be $43.44 \mathrm{~cm}^{3}$. By the use of helium porosimeter, grain volume and porosity were found to be $38.69 \mathrm{~cm}^{3}$ and $10.93 \%$. Porosity value shows that it was compact sandstone type, and gradation of reservoir porosity was found to be low porosity (Xuetao Hu and Su Huang 2017).

\section{Determination of Permeability}

The permeability of the sandstone was measured in gas permeameter and found to be $0.084 \mathrm{mD}$. Gradation of reservoir permeability was observed to be ultra-low permeability. The ultra-low permeability of core sample makes tight sandstone type (Xuetao Hu and Su Huang 2017).

\section{Core Flooding Operation}

The various parameters such as PV (ml), OOIP (ml), $\mathrm{S}_{\text {orwf }}, \mathrm{S}_{\mathrm{orcf}}, \mathrm{S}_{\mathrm{wi}}(\%), \mathrm{S}_{\mathrm{oi}}(\%), \mathrm{S}_{\mathrm{or}}(\%), \mathrm{A}_{\text {or }}(\%)$ monitored for determination oil recovery, and also we can observe the ability of chemical surfactant to enhance the oil recovery in the core flooding column(Rajesh Kanna A et al 2014). The brine flooding step can be considered analogous to the water flooding operation in oil well during secondary phase oil recovery. After water flooding, the residual oil saturation was reached in the range of $54.44 \%$ in the column (Samadi NN et al 2007). The trapping of oil in core column mimics the situation in oil well, where the oil gets trapped in the pores of rocks. To recover the oil trapped in the sand pack column, Triton X-100 was passed in the oil saturated core column and after $24 \mathrm{~h}$ of incubation, the oil displaced from the core was recovered and percentage additional oil recovery (AOR) was calculated. The oil recovery efficiency of water flooding and chemical flooding was found to be $35 \%$ and $42.23 \%$. The recovery of crude oil was slightly less in the water flooding mechanism due to the low porosity and permeability of sandstone (Suthar H et al 2008). 


\section{CONCLUSIONS}

Sandstone is a consolidated sand particle along with the compaction materials of rock fragments and clay. The sand particle size distribution was ranging from 0.06 to $2 \mathrm{~mm}$. The investigated sandstone was a regular cylindrical shape and bulk volume of sandstone was found to be $43.44 \mathrm{~cm}^{3}$. The grain volume and porosity of sandstone were $38.69 \mathrm{~cm}^{3}$ and $10.93 \%$ while permeability of sandstone was $0.084 \mathrm{mD}$. The ultra-low porosity and low permeability make a tight sandstone kind. The large amount of white colour shows a cementation material that crafted the tight compaction, reduction in porosity and permeability.

The recovery of crude oil will be better in high porous and permeable rocks compared to low porous and permeable rocks. The core flooding operation was applied for the collected sandstone sample, in order to determine the recovery efficiency of a specific medium crude oil. The recovery of medium crude oil from water drive and chemical flooding were slightly less effective due to the ultra-low porosity and permeability. The study of core sample helps in better understanding of reservoir rock, which in turn assists crude oil recovery. Low permeability and porosity problems in the formation can be solved by the method of fracturing.

\section{REFERENCES}

1. A. Hurst and J. S. Archer.(1986). Sandstone Reservoir Description: An Overview of the Role of Geology and Mineralogy. clay minerals. 21, 791-809.

2. Leo C. van Rijn. (2013). Sedimentation of Sand and Mud in Reservoirs in Rivers. Website www.leovanrijn-sediment.com.

3. Robert R. Berg. (1986). Reservoir Sandstones. Published by Prentice-Hall, Inc., New Jersey 07632.

4. SKAT. (1992). Quality control guidelines for fibre or micro concrete tiles. pp. 67.

5. S. N. Ehrenberg and P. H. Nadeau. (2005). Sandstone vs. carbonate petroleum reservoirs: A global perspective on porositydepth and porosity-permeability relationships. AAPG Bulletin, v. 89, no. 4. pp. 435-445.

6. Teoh Ying Jia. (2007). Characteristics of Sedimentary Facies and Reservoir Properties of Some Tertiary Sandstones in Sabah and Sarawak, East Malaysia.

7. Xuetao Hu and Su Huang. (2017). Physics of Petroleum Reservoirs, Petroleum Industry Press and Springer-Verlag Berlin Heidelberg.

8. Sreenivasulu, S., \& Yogesh, K. Compressive Properties Of Polycarbonate Toughened Epoxy-Bamboo Fiber Composites.

9. Rajesh Kanna A, Suresh Kumar G and Sathyanaryana N. Gummadi. (2014). Bio-surfactant production and its application in microbial EOR. International Journal of Biological, Biomolecular, Agricultural, Food and Biotechnological Engineering, Vol: 8, No: 10 .

10. Samadi N. N, Abadian A, Akhavan M. R, Fazeli A, Tahzibi and Jamalifar H. (2007). Biosurfactant production by the strain isolation from contamination soil, J. of Research Bio. Sci. 7(7):1266-1269.

11. Suthar, H., Hingurao, K., Desai, A., Nerurkar, A. (2008). Evaluation of bioemulsifier mediated microbial oil recovery using sand pack column, Journal of Microbiological Methods, 75, 225-230. 
